\title{
Fluoride concentrations in the water of Maringá, Brazil, considering the benefit/risk balance of caries and fluorosis
}

Edmara Tatiely Pedroso BERGAMO(a) Marlon BARBANA(b)

Raquel Sano Suga TERADA ${ }^{(b)}$

Jaime Aparecido CURY(c)

Mitsue FUJIMAKI (b)

(a) Universidade Estadual de Campinas UNICAMP, Piracicaba Dental School, Department of Prosthodontics and Periodontology, Piracicaba, SP, Brazil.

(b) Universidade Estadual de Maringá - UEM, Department of Dentistry, Maringá, PR, Brazil.

(c) Universidade Estadual de Campinas UNICAMP, Piracicaba Dental School, Department of Physiological Sciences, Piracicaba, SP, Brazil.

Declaration of Interests: The authors certify that they have no commercial or associative interest that represents a conflict of interest in connection with the manuscript.

Corresponding Author:

Mitsue Fujimaki

E-mail:mfujimaki@uem.br

DOI: 10.1590/1807-3107BOR-2015.vol29.0047

Submitted: Sep 22, 2014

Accepted for publication: Dec 01, 2014

Last revision: Feb 05, 2015
Abstract: Current Brazilian law regarding water fluoridation classification is dichotomous with respect to the risks of and benefits for oral diseases, and fluoride (F) concentrations less than 0.6 or above $0.8 \mathrm{mg}$ F/L are considered outside the normal limits. Thus, the law does not consider that both caries and fluorosis are dependent on the dosage and duration of fluoride exposure because they are both chronic diseases. Therefore, this study evaluated the quality of water fluoridation in Maringá, PR, Brazil, considering a new classification for the concentration of $\mathrm{F}$ in water the supply, based on the anticaries benefit and risk of fluorosis (CECOL/USP, 2011). Water samples $(n=325)$ were collected monthly over one year from 28 distribution water networks: 20 from treatment plants and 8 from artesian wells. $\mathrm{F}$ concentrations were determined using a specific ion electrode. The average F concentration was $0.77 \mathrm{mg} \mathrm{F} / \mathrm{L}$ (ppm F), ranging from 0.44 to $1.22 \mathrm{mg} \mathrm{F} / \mathrm{L}$. Considering all of the water samples analyzed, $83.7 \%$ of them presented from 0.55 to $0.84 \mathrm{mg} \mathrm{F} / \mathrm{L}$, and according to the new classification used, they would provide maximum anticaries benefit with a low risk of fluorosis. This percentage was lower (75.4\%) in the water samples supplied from artesian wells than from those distributed by the treatment plant (86\%). In conclusion, based on the new classification of water $\mathrm{F}$ concentrations, the quality of water fluoridation in Maringá is adequate and is within the range of the best balance between risk and benefit.

Keywords: Fluoridation; Fluorides; Water Supply.

\section{Introduction}

The importance of adding fluoride to public water supply treatment facilities is based on evidence, ${ }^{1,2}$ and since it was implemented as a public health strategy for preventing caries more than 60 years ago, the balance between the anticaries benefit of fluoride and the risk of dental fluorosis has been discussed. A fluoride concentration range of 0.7 to $1.2 \mathrm{mg} \mathrm{F} / \mathrm{L}^{3}$ in water was established for the USA based on maximum environmental temperatures, considering that within this range, the effects of fluoride would be "optimal" regarding benefit/risk. In Brazil, according to Ordinance 635/BSB/1975, the recommended fluoride concentration in water for most cities is between 0.6 and $0.8 \mathrm{mg} \mathrm{F} / \mathrm{L}$, with an optimum level of $0.7 \mathrm{mg} \mathrm{F} / \mathrm{L}$. Nevertheless, the expansion of the national program for water fluoridation 
to locations with different climatic conditions has justified the need to review this ordinance ${ }^{5}$ so that it now requires a more adequate dosage to provide the maximum benefit of caries reduction with the minimum risk of dental fluorosis.

From a health surveillance perspective, in terms of water fluoridation assessment in Brazil, fluoride at levels less than 0.6 or greater than $0.8 \mathrm{mg} \mathrm{F} / \mathrm{L}$ is considered to be outside the acceptable limits. The current classification of fluoride concentration in the water supply is dichotomous and does not consider that both the concentration and duration of fluoride exposure through the water supply can lead to dental caries ${ }^{6}$ or fluorosis ${ }^{7}$ development. Hence, occasional variations less than or greater than optimal fluoride concentrations in water should not be interpreted by surveillance services for water quality control in the same manner as for other contaminants, such as fecal coliform, which is responsible for acute problems in the population.

Caries is a chronic disease caused by dental biofilm accumulation and frequent exposure to sucrose. Caries lesions are found only when the teeth are subjected to the caries process several times per day for many days. ${ }^{8}$ However, early caries lesions can be halted or even repaired, and fluoride is a potent activator of this process. ${ }^{9}$ Similarly, regarding fluorosis, several days of exposure to high fluoride concentrations are necessary during enamel formation for visible changes to be clinically detected in the future. ${ }^{10}$

In 2011, a new classification for F concentrations in public water supplies, proposed by the Centro Colaborador do Ministério da Saúde em Vigilância da Saúde Bucal da Universidade de São Paulo - CECOL/USP, was approved by the academic community and by experts and professionals responsible for water treatment. ${ }^{11}$ Therefore, the aim of this study was to evaluate the quality of water fluoridation in Maringá, Paraná, Brazil over a period of one year using a new classification of $\mathrm{F}$ concentration based on anticaries benefit and risk of fluorosis.

\section{Methodology Place of Research}

Maringá is located in southern Brazil, in the northwestern State of Paraná, and it has a population of 357.177 inhabitants. ${ }^{12}$ The maximum average local temperature during the period in which this study was conducted was $27.99^{\circ} \mathrm{C}$ (data provided by the Climatological Station of the Universidade Estadual de Maringá - UEM). The drinking water of Maringá is treated and distributed by the Companhia de Saneamento do Paraná-SANEPAR. In 2010, the water supply came mainly $(90 \%)$ from the Pirapó River to a single water treatment plant (WTP). The remaining $10 \%$ was obtained from seven deep artesian wells (AWs). All the water is treated conventionally with chlorination and fluoridation, the latter by adding fluorosilicic acid by means of a solution-feeder system.

\section{Selection and Collection of Samples}

Twenty-eight Basic Health Units (BHUs) were selected for water sample collection because of their representative geographical distribution in the water treatment network. Twenty-one BHUs received water from the WTP and 7 from AWs. The number of samples selected in the survey was based on the 518/GM Ordinance of March 25,2004 , which recommended a minimum of 20 samples for cities with more than 250 thousand inhabitants, adding one sample for every 50,000 additional inhabitants. ${ }^{13}$

Health workers from the 28 BHUs collected water samples at the same time on the same day of the week over the 12 months. The water was collected from the distribution network and placed in plastic bottles. The collectors were trained to standardize the collection process, which consisted of letting the water run for 30 seconds, rinsing the bottles 3 times with the water and collecting approximately $5 \mathrm{~mL}$ of water for analysis. The water samples were codified using numbers 1 to 28 , allowing for blind fluoride determination. The samples were immediately sent to an independent laboratory for analysis.

\section{Fluoride Determination}

The analysis was performed by the Laboratory of Oral Biochemistry, Faculty of Dentistry of Piracicaba UNICAMP using an ion-specific electrode. Duplicate samples were buffered with the same volume of TISAB II (1.0 M acetate buffer $\mathrm{pH} 5.0,1.0 \mathrm{M} \mathrm{NaCl}$ and $0.4 \%$ CDTA), prepared in the laboratory. An Orion 96-09 electrode (Thermo Scientific Inc., Waltham, USA) 
coupled to an Orion EA-940 ion analyzer (Thermo Scientific Inc., Waltham, USA) was calibrated with standard solutions at concentrations ranging from F 0.25 to $2.00 \mathrm{mg} \mathrm{F} / \mathrm{mL}$, containing 50\% of TISAB II. The results were expressed in $\mathrm{mg} \mathrm{F} / \mathrm{L}$ (ppm F), and the coefficient of variation for the duplicate analysis was less than $1 \%$.

\section{Classification of the Results}

The samples were classified according to a new classification of Fluoride concentrations in drinking water proposed in Brazil (CECOL/USP, 2011), considering the balance between anticaries benefit and risk of the fluorosis, as shown in Table $1 .^{11}$

\section{Statistical Analysis}

The results are presented with a descriptive statistical analysis of the data.

\section{Results}

The mean concentration of the 325 water samples analyzed was $0.77 \mathrm{mg} \mathrm{F} / \mathrm{L}$, ranging from $0.44 \mathrm{ppm}$ to $1.22 \mathrm{ppm} F$.

Considering all of the water samples from the WTP and AWs, Table 2 shows that, except for July, more than $78.5 \%$ (mean of $83.7 \%$ ) of the samples presented a concentration from 0.55 to $0.84 \mathrm{mg} \mathrm{F} / \mathrm{L}$, within the optimal balance between anticaries benefit and the minimum risk of fluorosis.

Table 1. Balance between anticaries benefit and risk of fluorosis expected according to the range of $F$ concentrations in water for cities with maximum temperatures ranging from $26.3^{\circ} \mathrm{C}$ to $32.5^{\circ} \mathrm{C}$.

\begin{tabular}{lcc}
\hline F concentration $(\mathrm{mg} \mathrm{F} / \mathrm{L})$ & & Balance \\
\cline { 2 - 3 } 0.00 to 0.44 & Anticaries benefits & Risk of fluorosis \\
0.45 to 0.54 & Insignificant & Insignificant \\
0.55 to 0.84 & Minimum & Low \\
0.85 to 1.14 & Maximum & Low \\
1.15 to 1.44 & Maximum & Moderate \\
$>1.45$ & Questionable & High \\
\hline
\end{tabular}

Table 2. Classification (\%) of all water samples, from water treatment plants (WTPs) and artesian wells (AWs), classified according to the ranges of $\mathrm{F}$ concentrations regarding the risks and benefits, according to the month of evaluation.

\begin{tabular}{|c|c|c|c|c|c|c|}
\hline \multirow{2}{*}{ Evaluation month (number of samples) } & \multicolumn{6}{|c|}{ F concentration range (mg F/L) } \\
\hline & 0.00 to $0.44^{*}$ & 0.45 to $0.54^{* *}$ & 0.55 to $0.84^{* * *}$ & 0.85 to $1.14^{* * * *}$ & 1.15 to $1.44^{* * * * *}$ & $>1.45^{* * * * * *}$ \\
\hline $\mathrm{Jul} / 09(\mathrm{n}=26)$ & 0 & 0 & 4 & 96 & 0 & 0 \\
\hline Aug/09 $(n=26)$ & 0 & 4 & 92 & 4 & 0 & 0 \\
\hline Sep/09 $(n=28)$ & 3.5 & 0 & 89.5 & 3.5 & 3.5 & 0 \\
\hline Oct/09 $(n=28)$ & 0 & 0 & 96 & 4 & 0 & 0 \\
\hline Nov/09 $(n=28)$ & 0 & 3.5 & 78.5 & 18 & 0 & 0 \\
\hline $\mathrm{Dec} / 09(\mathrm{n}=27)$ & 0 & 0 & 100 & 0 & 0 & 0 \\
\hline $\operatorname{Jan} / 10(n=27)$ & 0 & 7.5 & 92.5 & 0 & 0 & 0 \\
\hline $\mathrm{Feb} / 10(\mathrm{n}=27)$ & 0 & 0 & 81.5 & 18.5 & 0 & 0 \\
\hline $\mathrm{Mar} / 10(\mathrm{n}=27)$ & 0 & 0 & 92 & 4 & 4 & 0 \\
\hline Apr $/ 10(n=27)$ & 0 & 4 & 92 & 4 & 0 & 0 \\
\hline May/10 $(n=27)$ & 0 & 0 & 92 & 8 & 0 & 0 \\
\hline Jun/10 ( $=27)$ & 0 & 0 & 89 & 11 & 0 & 0 \\
\hline Total $(n=325)$ & 0.3 & 1.6 & 83.7 & 13.8 & 0.6 & 0 \\
\hline
\end{tabular}

*Insignificant benefit/risk; ${ }^{* *}$ Minimum benefit/low risk; ${ }^{* * *}$ Maximum benefit/low risk; ${ }^{* * * *}$ Maximum benefit/moderate risk; ${ }^{* * * * *}$ Questionable benefit/high risk; ${ }^{* * * * * * H a r m f u l ~ e f f e c t / v e r y ~ h i g h ~ r i s k . ~}$ 
When comparing the mean values of water samples from the WTP and AWs, $86 \%$ of the samples from the WTP were found to present an F concentration within the best balance of benefit and risk (from 0.55 to $0.84 \mathrm{mg} \mathrm{F} / \mathrm{L}$ ), while $75.4 \%$ of the samples from AWs were within this range. In addition, the percentage of samples with insignificant benefit $(<0.45 \mathrm{mg} \mathrm{F} / \mathrm{L})$ and greater risk $(>1.14 \mathrm{mg} \mathrm{F} / \mathrm{L})$ was higher among the water samples from AWs than from the WTP, at $2.6 \%$ and $0.4 \%$, respectively.

\section{Discussion}

Fluoride works on caries control by interfering with the processes of de- and remineralization of the tooth. It decreases mineral loss when it is present in the oral cavity in low and constant concentrations, ${ }^{14}$ and it consequently reduces the rate of caries progression in the population. However, when fluoride is ingested during enamel mineralization, dental fluorosis can develop. ${ }^{15}$ Thus, an adequate concentration of $\mathrm{F}$ in drinking water is necessary for water fluoridation to reach its maximum anticaries benefit with a minimum risk of fluorosis. ${ }^{11}$

Data from this study showed that $83.7 \%$ of all of the water samples analyzed were within the range of best benefit and least risk, considering the new classification proposed by CECOL/USP. ${ }^{11}$ In contrast, had the samples been classified by Ordinance $635 / \mathrm{BSB} / 1975,{ }^{4}$ only $68.7 \%$ of the samples would have been within the acceptable range. This difference of $15 \%$ of samples outside of the range established by the current ordinance could suggest that the population of Maringá was not being subjected to the optimal balance of caries benefit and risk of fluorosis in the drinking water. However, this interpretation is not valid because the range of optimal fluoride concentration in water was established 60 years ago, when the understanding of how fluoride controls caries and causes/leads to fluorosis differed from the currently accepted understanding. Both caries ${ }^{6}$ and fluorosis ${ }^{7}$ are chronic diseases, so the duration of exposure to a low or high Fluoride concentration should be considered. ${ }^{16}$ Thus, in terms of the risk of fluorosis, the findings (Table 2) showed that samples within the range of a high risk of fluorosis were found only in two months $3.5 \%$ in September and
$4 \%$ in March). With regard to caries, samples (3.5\%) of insignificant anticaries benefit were found only in September. Therefore, brief fluctuations greater than or less than the ideal range of fluoride concentration in water should be considered tolerable. According to the CECOL/USP classification, ${ }^{11}$ Fluoride concentrations of insignificant benefit or very high risk could be considered tolerable if they occurred sporadically for one day over a few months, and concentrations of moderate risk or benefit could be acceptable only if they did not remain constant for more than 21 days over the course of a one-year period. This new classification seems more rational in terms of water evaluation, considering the benefit/risk of Fluoride concentration. Therefore, if $31.3 \%$ of water samples from Maringá had been classified by the current ordinance ${ }^{4}$ they would have been considered unacceptable by the Brazilian surveillance system, whereas if the new classification were used as reference, only half of these samples would be unacceptable (15.3\%). This more conservative classification is supported by the current data regarding caries and fluorosis in Brazil. ${ }^{17}$

When this new classification of fluoride concentration in water is used instead of the current ordinance, a lower percentage of unacceptable samples would also be found in other cities, e.g., Jaguaribara, $\mathrm{CE}_{1}^{18}$ and Bauru, SP. ${ }^{19}$ However, while only approximately $66 \%$ of the samples in these cities were within the range of greater benefit of Fluoride in preventing dental caries and a lower risk of fluorosis, this value was higher in Maringá, PR (84\%).

Ordinance 635/BSB $/ 1975^{4}$ has been used in most of the evaluations of the quality of water fluoridation in Brazil that have been undertaken, showing discrepant values. In Cachoeiras do Sul, RS, in Piracicaba, SP, and in a study of 29 Brazilian cities $63.4 \%{ }^{20}, 85 \%{ }^{21}$ and $53.5 \%{ }^{22}$ of the samples, respectively, were within acceptable levels. In contrast, in Ponta Grossa, PR, two-thirds of the samples were outside the ideal level; ${ }^{23}$ in the state of Piauí, only $4.3 \%$ of samples were within the optimal range, ${ }^{24}$ and $53.6 \%$ of the samples from the island of São Luis, MA, were less than the optimal range, ${ }^{25}$ compromising the benefits of the fluoridation process. A survey conducted in the database of the Laboratory of Oral Biochemistry, Piracicaba Dental School, UNICAMP, showed that $40 \%$ of the samples 
collected were outside the acceptable standards. ${ }^{26}$ If these results were interpreted based on the new classification proposed by CECOL/USP, the percentage of sample within the range of best benefit/least risk certainly would be higher.

When the results found in Maringá, PR, are analyzed in consideration of the origin of the water treatment, from AWs or the WTP, the percentage of samples outside the range of maximum benefit of fluoride and least risk of fluorosis was higher from the AWs (24.6\%) than from the WTP (14\%). These data suggest that is more difficult control the fluoridation from AWs than WTPs, in agreement with the data from other studies conducted in Capão Bonito ${ }^{27}$ and Araçatuba, SP. ${ }^{28}$ However, in terms of the risk of fluorosis, the findings showed that only one sample from one month was within the range of high risk of fluorosis for water from AWs (14\% in September) and from the WTP $(5 \%$ in March). Regarding caries, only one sample from one month would have subjected the population to insignificant anticaries benefit (14\% in September) and then only for samples originating from AWs. Despite the difference in the percentage of samples, this value

\section{References}

1. Yeung CA. A systematic review of the efficacy and safety of fluoridation. Evid Based Dent. 2008;9(2):39-43.

2. Marinho V, Tenuta LMA, Cury JA. Use of fluorides in the control of dental caries. In: Sheiham A, Moysés SJ, Watt RG, Bonecker M. Promoting the oral health of children: theory and practice. 2nd ed. São Paulo: Quintessence; 2014. p. 225-42.

3. Centers for Disease Control and Prevention. Engineering and administrative recommendations for water fluoridation, 1995. MMWR Recomm Rep. 1995 Sep 29;44(RR-13):1-40.

4. Brasil. Lei n. 6050 de 24 de Maio de 1974. Dispõe sobre a fluoretação da água em sistemas de abastecimento público quando existir estação de tratamento. Diário Oficial da União, Brasília (1974 may 27); Sec.1:6021.

5. Frazao P, Peres MA, Cury JA. Drinking water quality and fluoride concentration. Rev Saude Publica. 2011 Oct;45(5):964-73.

6. Tenuta LMA, Cury JA. Fluoride: its role in dentistry. Braz Oral Res. 2010 Jul;24(Spec Iss 1):9-17.

7. Bardsen A. Risk periods associated with the development of dental fluorosis in maxillary permanent central incisors: a meta-analysis. Acta Odontol Scand. 1999 Oct;57(5):247-56.

8. Ccahuana-Vásquez RA, Tabchoury CP, Tenuta LMA, Del Bel Cury AA, Vale GC, Cury JA. Effect of frequency of sucrose exposure of insignificant benefit occurred in only one month, and as previously discussed, these brief fluctuations above or below the ideal range of fluoride concentration in water should be considered tolerable. ${ }^{11}$

\section{Conclusions}

Considering the results and the current knowledge regarding caries and fluorosis, the population of Maringá, PR, receives water within the range that provides the best balance between anticaries benefit and the dental risk of fluorosis.

\section{Acknowledgements}

We appreciate the partnership with SANEPAR (Companhia de Saneamento do Paraná) and the Secretaria de Saúde de Maringá, the dental health coordinator Dr. Leticia Padovez, the oral health technicians, oral health assistants, and dental surgeons and all who contributed to the collection of water in the Basic Health Units (Unidades Básicas de Saúde). This study was supported by the Pró-Saúde Project of UEM Dental School (Brazilian Interministerial Ordinance no. 2101, November 3, 2005).

on dental biofilm composition and enamel demineralization in the presence of fluoride. Caries Res. 2007;41(1):9-15.

9. Cury JA, Tenuta LMA. Enamel remineralization: controlling the caries disease or treating early caries lesions? Braz Oral Res. 2009;23(Suppl 1):23-30.

10. Catani DB, Hugo FN, Cypriano S, Sousa MLR, Cury JA. Relationship between fluoride levels in the public water supply and dental fluorosis. Rev Saude Publica. 2007 Oct;41(5):732-9.

11. Centro Colaborador do Ministério da Saúde em Vigilância da Saúde Bucal. Consenso técnico sobre classificação de águas de abastecimento público segundo o teor de flúor. São Paulo: Faculdade de Saúde Pública da Universidade de São Paulo; 2011.

12. Prefeitura do município de Maringá. IBGE divulga população de 357.117 habitantes para Maringá. [Internet]. Maringá: Prefeitura do município de Maringá; [cited 2010 Nov 29]. Available from: http://www2.maringa.pr.gov.br/site/index. php?sessao=0e26112f28550e\&id=121.

13. Brasil. Ministério da Saúde. Estabelece os procedimentos e responsabilidades relativos ao controle e vigilância da qualidade da água para consumo humano e seu padrão de potabilidade, e dá outras providências. Portaria n. 518, 25 março 2004. Diário Oficial da União. 2004 mar.: 266-70. 
14. Tenuta LMA, Chedid SJ, Cury JA. Uso de fluoretos em odontopediatria: mitos e evidências. In: Maio LC, Primo LG. Odontopediatria Clínica Integral. São Paulo: Santos; 2012. p. 153-177.

15. Aoba T, Fejerskov O. Dental fluorosis: chemistry and biology. Crit Rev Oral Biol Med. 2002 Mar;13(2):155-70.

16. Catani DB, Hugo FN, Cypriano S, Souza MLR, Cury JA. Relação entre níveis de fluoreto na água de abastecimento público e fluorose dental. Rev Saude Publ. 2007 May;41(5):7329. Portuguese, English.

17. Brasil. Ministério da Saúde. SB Brasil 2010: Pesquisa Nacional de Saúde Bucal, resultados principais. Brasília: Ministério da Saúde; 2012. 117 p.

18. Peixoto DF, Alencar KP, Peixoto RF, Souza CFM, Sampaio FC, Forte FDS. Heterocontrole da fluoretação da água de abastecimento público do município de Jaguaribara, Ceará, Brasil. Rev Bras Prom Saude. 2012 Jul-Sep;25(3):271-7.

19. Buzalaf MAR, Moraes CM, Olympio KPK, Pessan JP, Grizzo LT, Silva TL, et al. Seven years of external control of fluoride levels in the public water supply in Bauru, São Paulo, Brazil. J Appl Oral Sci. 2013 Jan-Feb;21(1):92-8.

20. Piva F, Tovo MF, Kramer PF. Heterocontrole da fluoretação da água de abastecimento público do município de Cachoeira do Sul - RS. Rev Fac Odontol Porto Alegre. 2006 Aug;47(2):29-32.

21. Amaral RC, Wada RS, Sousa MLR Concentração de fluoreto nas águas de abastecimento público relacionada à temperatura em Piracicaba - SP. Rev Fac Odontol Passo Fundo. 2007 Sep-Dec;12(3):24-8.
22. Moimaz SAS, Saliba O, Chiba FY, Saliba NA. External control of public water supply in 29 Brazilian cities. Braz Oral Res. 2012 Jan-Feb;26(1):12-8.

23. Wambier DS, Pinto MHB, Kloth AEG, Vetorazzi ML, Ditterich RG, Oliveira DK. Análise do teor de flúor nas águas de abastecimento público de Ponta Grossa-PR: dez meses de heterocontrole. Publ UEPG Biol Health Sci. 2007 MarJun;13(1/2):65-72.

24. Silva JS, Val CM, Costa JN, Moura MS, Silva TAE, Sampaio FC. Heterocontrole da fluoretação das águas em três cidades no Piauí, Brasil. Cad Saude Publica. 2007 May;23(5):1083-8.

25. Carmo CDS, Alves CMC, Cavalcante PR, Ribeiro CCC. Avaliação da fluoretação da água do sistema de abastacimento público na Ilha de São Luís, Maranhão, Brasil. Cien Saude Colet. 2010 Jun;15 Suppl 1:1835-40.

26. Catani DB, Amaral RC, Oliveira C, Sousa MLR, Cury JA. Dez anos de acompanhamento do heterocontrole da fluoretação da água feito por municípios brasileiros, Brasil, 1996-2006. Rev Gaucha Odontol.. 2008 Apr-Jun;56(2):151-5.

27. Olivati FN, Sousa MLR, Tenuta LMA, Cury JA. Quality of drinking water fluoridation of Capão Bonito, SP, Brazil, evaluated by operational and external controls. Rev Odonto Cien. 2011;26(4):285-90.

28. Daré F, Dall'áglio Sobrinho M, Libânio M. Avaliação do processo de fluoretação nos sistemas de abastecimento de água da região de Araçatuba, São Paulo. Eng Sanit Ambient. 2009 Apr-Jun;14(2):173-82. 